\title{
Timing of $M$. tuberculosis exposure explains variation in BCG effectiveness: A systematic review and meta-analysis
}

\section{Short title}

Timing of exposure to infection explains variation in BCG protection

\section{Authors}

James M Trauer, ${ }^{1}$ Andrew Kawai, ${ }^{1}$ Anna Coussens, ${ }^{2}$ Manjula Datta, ${ }^{3}$ Bridget M Williams, ${ }^{1}$ Emma S McBryde, ${ }^{4}$ Romain Ragonnet. ${ }^{1}$

\section{Affiliations}

1. Epidemiological Modelling Unit, School of Public Health and Preventive Medicine, Monash University, Melbourne 3004, Australia

2. Walter and Eliza Hall Institute of Medical Research, Parkville 3053, Australia

3. ASPIRE, A Society for Primary health care Intervention, Research and Education, Thiruvallur 602003, India

4. Australian Institute of Tropical Health and Medicine, James Cook University, Douglas 4814, Australia

\section{Corresponding author}

Associate Professor James Trauer, Head of Epidemiological Modelling

School of Public Health and Preventive Medicine, Monash University

553 St Kilda Road, Melbourne, Victoria 3004, Australia

james.trauer@monash.edu, +61 $399030798,+61403260064$ 
medRxiv preprint doi: https://doi.org/10.1101/2020.11.26.20239533; this version posted November 30, 2020. The copyright holder for this preprint (which was not certified by peer review) is the author/funder, who has granted medRxiv a license to display the preprint in perpetuity. It is made available under a CC-BY-NC 4.0 International license .

\section{Contributors}

JMT designed the study. AK and JMT designed and performed the literature search. AK, JMT, RR and BMW contributed to data extraction and analysis.

\section{Funding}

No specific funding was received for this project. James Trauer is a recipient of an Early Career Fellowship from the Australian National Health and Medical Research Council (APP1142638). 


\section{Abstract}

\section{Background}

The variable efficacy observed in studies of BCG vaccination is incompletely explained by currently accepted hypotheses, such as latitudinal gradient in non-tuberculous mycobacteria exposure. We investigated heterogeneity in BCG vaccination in the context of participant demography, diagnostic approach and TB-related epidemiological context.

\section{Methods}

We updated previous systematic reviews of the effectiveness of BCG vaccination to $31^{\text {st }}$ December 2018. We employed an identical search strategy and inclusion/exclusion criteria to past reviews, but reclassified several studies and developed an alternative classification system.

\section{Results}

Of 21 included trials, those recruiting neonates and children aged under five were consistent in demonstrating considerable protection for several years. Trials in high-burden settings with shorter follow-up also showed considerable protection, as did most trials in settings of declining burden with longer follow-up. However, the few trials performed in high-burden settings with longer follow-up showed no protection, sometimes with higher case rates in the vaccinated than the controls in the later follow-up period.

\section{Conclusions}

The most plausible explanatory hypothesis is that BCG protects against TB that results from exposure shortly after vaccination. However, risk is equivalent or increased when exposure occurs later from vaccination, a phenomenon which is predominantly observed in adults in highburden settings with longer follow-up. In settings of declining burden, most exposure occurs shortly following vaccination and the sustained protection thereafter represents continued 
medRxiv preprint doi: https://doi.org/10.1101/2020.11.26.20239533; this version posted November 30, 2020. The copyright holder for this preprint (which was not certified by peer review) is the author/funder, who has granted medRxiv a license to display the preprint in perpetuity. It is made available under a CC-BY-NC 4.0 International license .

protection against this early exposure. By contrast, in settings of continued intense transmission, initial protection subsequently declines due to repeated exposure to $M$. tuberculosis or other pathogens.

\section{Key words}

tuberculosis; Mycobacterium bovis; vaccination; immunization; global health 


\section{Introduction}

Tuberculosis (TB) is the world's leading infectious disease killer (1), and Bacille CalmetteGuérin (BCG) is the only approved vaccine for its control. Global BCG coverage was $88 \%$ in 2019, close to the highest coverage of any vaccination (2). The substantial heterogeneity in the efficacy of BCG vaccination between studies has long been recognised, with study-level variables such as age, latitude and BCG strain able to explain some of this variation in metaanalyses unrestricted by age (3-5).

Past attempts to understand this heterogeneity have often started from the assumption that protection wanes with time from vaccination $(6,7)$. However, time since vaccination parallels immunological maturation and changing TB phenotype (8-10), which may lead to confounding. While retrospective national health data have shown that vaccine effectiveness can be sustained for $>15$ years $(11,12)$, multiple observational studies in low-burden settings have found that past history of BCG vaccination significantly increases risk in contacts of TB patients $(13,14)$.

These observations suggest that intensity or timing of $M t b$ exposure relative to age and time since vaccination may be important in determining vaccine effectiveness. However, no coherent theoretical framework has been proposed to explain the diversity of results and the adverse effects of BCG sometimes observed. Because of the markedly different disease phenotypes and onset timing with age of exposure $(14,15)$, we reviewed evidence for the efficacy of BCG vaccination with a focus on TB-related epidemiology, diagnostic approach, time from vaccination and age. 


\section{Methods}

\section{Reference management}

We performed a systematic review of studies of the effect of BCG vaccination on TB disease, including sub-categories of TB disease, with search strategy and inclusion/exclusion criteria identical to Abubakar 2014 (5) and consistent with our PROSPERO-registered protocol (CRD42019119676), but with search dates extended to 31 ${ }^{\text {st }}$ December 2018 (Section 2, Supplemental Appendix). Details of our search strategy are presented in Section 7 of the Supplemental Appendix. We focused on clinical trials as the highest form of evidence, but also reviewed cohort studies as a secondary level of evidence, as presented in the study profile (Figure 1). We considered studies comparing participants receiving their first BCG vaccination against unvaccinated controls, excluding trials of BCG revaccination, consistent with previous reviews. No further eligible trials were identified that had not been included in the earlier review, with the recent trial of placebo, H4:IC31 vaccine and BCG (which observed no TB cases, personal communication, Hatherill) excluded as a revaccination trial (16). All data extracted from studies published from 2009 to 2018 were reviewed by two authors (which pertains to cohort studies only).

\section{Data extraction}

We describe all trials in detail in our extended narrative review (Sections 3-11, Supplemental Appendix). Unlike previous reviews $(4,5,17)$, we considered how age-specific reactivation profiles may be influenced by the background intensity of $M t b$ transmission and formulated a new classification for included trials and conceptual framework for integrating their results. Specifically, we considered participant age, background TB burden and duration of follow-up as the main factors in classifying included trials. Trials not exclusively recruiting neonates have 
previously been grouped according to study-level factors, including: stringency of latent TB infection (LTBI) testing, as either single or multiple tests; and age group, as either school-aged or other age. However, previous reviews classified several studies as "other age", even though most participants were children, which we believe is misleading $(4,5)$. We also identified errors in the previous reviews (Section 2.3, Supplemental Appendix), including two major trials incorrectly assigned according to the authors' classification system, with the differences between our results and those of the previous reviews confirmed by three authors blinded to each other's assessment (JMT, AK, RR).

Because the Chengalpattu trial was the largest ever trial of BCG vaccination, was performed in a high-burden setting and was relatively recent, we also obtained unpublished estimates from this study disaggregated by age and time from vaccination. To illustrate the interacting effects of age and time from vaccination, we extracted data from reports of trials for which data could be disaggregated by both age at TB diagnosis and time from vaccination, in combination with the previously unpublished data from the Chengalpattu trial.

\section{Data synthesis and analysis}

We used a hierarchical approach to estimating effect sizes, given the diverse approaches to presenting outcomes. Where possible we estimated effect sizes from information on person-years of follow-up and number of cases occurring in the vaccinated and unvaccinated groups. If this was unavailable, we estimated follow-up periods from the information provided (Section 2.2, Supplemental Appendix).

Meta-analysis was performed under our new classification with Stata version 16.1 (College Station, USA). The forest plot was generated using the random effects model of DerSimonian and Laird with the Mantel-Haenszel assessment of heterogeneity from the metan package, with 
medRxiv preprint doi: https://doi.org/10.1101/2020.11.26.20239533; this version posted November 30, 2020. The copyright holder for this preprint (which was not certified by peer review) is the author/funder, who has granted medRxiv a license to display the preprint in perpetuity.

It is made available under a CC-BY-NC 4.0 International license .

pooled effect size estimates and confidence limits also presented using REML with KnappHartung adjustment provided by Stata's meta function.

Stata code for meta-analysis, and the data and Python 3.6 code for generating Figure 2 and

Figure 3 are available at https://github.com/jtrauer/bcg_tb_context_review.

\section{Results}

Included studies are described in our detailed narrative review (Sections 3-11, Supplemental Appendix) and summarised as follows and in Table 2. Assessment of study quality according to standard criteria for the assessment of clinical trials has been undertaken in previous systematic reviews (Abubakar et al. 2013, Appendix 4) (5), and our assessments were in complete agreement with these findings.

\section{Neonatal vaccination trials}

Of 21 included trials we identified, six recruited neonates only (18-23). A small minority of the participants in the Saskatchewan native infants and New York infants trials received oral vaccination, but most infants in these trials received parenteral vaccination. The trial in New York infants reported on TB-related mortality but not TB incidence, finding eight deaths in each of the vaccinated and control groups during its alternate assignment period (24). Although the trial undertaken in the lowest resource and likely highest transmission setting reported the lowest efficacy, estimates of protection were homogeneous, with most trials consistent with the pooled estimate of approximately $60 \%$ protection (4). Follow-up duration varied, although none followed participants into or beyond adolescence in a setting of continued intense transmission. 
medRxiv preprint doi: https://doi.org/10.1101/2020.11.26.20239533; this version posted November 30, 2020. The copyright holder for this preprint (which was not certified by peer review) is the author/funder, who has granted medRxiv a license to display the preprint in perpetuity.

It is made available under a CC-BY-NC 4.0 International license .

\section{Trials recruiting young children}

Although the Agra trial was previously included with school-aged vaccination and is only reported very briefly, participants were aged $<5$ at entry (25). The point estimate of efficacy in this trial was $60 \%$ protection, consistent with estimates for neonates. The other trial recruiting the youngest children (previously classified as school-aged) observed three cases of TB, all among control participants, also consistent with high childhood efficacy (26).

\section{Reclassification of trials not restricted to young children}

The categorisation of these studies as "school" or "other" age fails to convey that many studies previously categorised as "other" age predominantly recruited children. This often occurred because of an expansive population age pyramid and/or inclusion criteria, typically including negative LTBI testing, the prevalence of which declines with age, particularly in high-burden settings. A prime example is the population-wide Haiti trial, in which TST-negativity in adults was so rare that the protocol was modified to exclude participants $>20$, resulting in a predominantly paediatric cohort (Figure 2) (27).

\section{Trials recruiting broadly across paediatric age ranges}

Three trials recruited across most or all paediatric age ranges to approximately 20 years (27-29). The Haitian trial observed participants for three years, with one case occurring in the vaccinated and five in the controls, suggesting good short-term protection in a high transmission setting (27). The large Puerto Rico trial (previously misclassified as non-stringent TST) was undertaken in a setting of rapidly declining but substantial burden, and showed modest efficacy $(29,30)$. The trial in native Americans was undertaken in a setting in which rates of disease rapidly declined to very low levels throughout most of follow-up, with sustained efficacy for $>60$ years $(19,28,31)$. 


\section{Paediatric/adolescent trials}

The trial in Georgia schools recruited ages 6 to 17, with the small number of cases that occurred all accruing after six years of follow-up $(30,32)$. The large MRC-funded trial was undertaken in school children in large English cities and found high efficacy in a setting of rapidly declining burden (Figure 3) $(33,34)$.

\section{Trials in young adults with shorter follow-up}

Three trials from Chicago of participants at high risk because of occupational or residential exposure risk were included in this category, along with one trial of participants at high occupational risk from a high-burden setting. The trial of mental health patients observed only one case of "bilateral minimal arrested tuberculosis" in 35 participants, providing little information. Two reports from Chicago describe BCG vaccination trials in students of nursing and medicine followed for the duration of their studies. Both were small and excluded from previous reviews for methodological limitations, with only eleven cases occurring across both trials $(4,35,36)$. The trial in South African mine workers was also excluded from past reviews for including some participants who were TST-positive at baseline (6), but found fewer cases in the vaccinated over 3.6 years of follow-up (37).

\section{Trials recruiting across all ages with extended follow-up}

The trial in Muscogee and Russell Counties, USA, achieved broad community participation in those aged $>5$ in a setting of low and declining transmission, finding slightly fewer cases in the vaccinated $(30,32)$. The trial in Lincoln State School describes an adult cohort followed in a high transmission setting and suggested a trend towards more cases in the vaccinated, particularly after five years of follow-up (Figure 3) (38). 
The Chengalpattu trial was the largest BCG vaccination trial ever undertaken and was among the best reported, although it employed one-stage TST screening (39). It enrolled participants aged one month and above, followed for 15 years in a very high transmission setting and found slightly higher TB rates in the BCG-vaccinated, although protection was suggested in children (40). The Madanapalle trial (41) followed participants for 21 years in a very high transmission setting and focused on the end-point of smear-positive TB, which likely explains the low number of paediatric cases (Figure 3) (9). Although previously classified as employing stringent TST testing, one-stage testing with a cut-off of $<5 \mathrm{~mm}$ was used in around $95 \%$ of participants. A critical point of distinction between these two trials is that Madanapalle, unlike Chengalpattu, was linked to a successful case finding campaign that led to dramatic falls in TB mortality during the study period (42).

\section{Meta-analysis}

Heterogeneity was not observed when studies were grouped according to our classification (Figure 4). The pooled estimate for the incidence rate ratio of BCG vaccination in trials of neonates and young children was 0.26 (95\%CI 0.17, 0.35). For other paediatric studies in highburden settings, we refer readers to the descriptions of the original trials. For paediatric studies with longer follow-up in settings of declining burden the incidence rate ratio was 0.25 (95\% CI 0.20, 0.30). Trials of adults in high-burden settings with short follow-up durations were methodologically heterogeneous, but the pooled estimate suggested benefit, with an incidence rate ratio of $0.59(95 \% \mathrm{CI} 0.31,0.87)$. Trials of adults with longer follow-up duration were all consistent with a null overall effect, with marginal protection was suggested in settings of declining burden and the Chengalpattu trial dominating the effect estimate in high-burden settings. 


\section{Cohort studies}

Very few cohort studies were undertaken in high-burden settings with extended follow-up, and none disaggregated rates by both age and time (Table 1, Supplemental Appendix). Many cohort studies were undertaken in settings of declining burden with short follow-up durations, with most suggesting high efficacy. Several studies in settings of declining burden (France, Norway, Greenland) with extended periods of follow-up (>15 years) supported a sustained protective effect. However, several cohort studies with shorter follow-up duration in higher exposure settings suggested no effect (either high-burden countries, some studies of TB contacts or groups with occupational exposure risk).

\section{Discussion}

Few trials of BCG vaccination followed participants for more than five years post-vaccination, but of those that did, settings with sustained exposure risk showed lower effectiveness than those in which risk predominantly accrued shortly after vaccination. Therefore, we propose that timing of $M t b$ exposure, rather than timing of TB disease, should be the main consideration in understanding the differences in BCG efficacy between settings (Table 1). In settings of rapidly declining TB burden, exposure is less likely further from vaccination and the effect of BCG in preparing the participant's immune system for early exposure is robust. By contrast, in sustained high-burden settings, participants are more likely to be exposed after a longer period from vaccination when BCG efficacy has waned or after re-exposure has occurred. This interpretation implies that BCG may have little effect or could increase longer term-risk in settings of persistent exposure. 
medRxiv preprint doi: https://doi.org/10.1101/2020.11.26.20239533; this version posted November 30, 2020. The copyright holder for this

It is made available under a CC-BY-NC 4.0 International license .

None of the eight studies of neonates or young children followed a substantial cohort of participants into the high-risk adolescent period in a high-transmission setting, but all were consistent with significant protection in early life. Among paediatric and adolescent trials, two larger studies in settings of declining burden showed substantial protection and one suggested short-term protection in a high-burden setting. In adults, four high-quality studies with long-term follow-up have been undertaken, with the two performed in high transmission settings suggesting an null or adverse effect $(38,39)$, while one in a low transmission setting $(30,32)$ and one linked to case finding (41) found modest protection. Methodologically heterogeneous trials with short follow-up of participants were also consistent with short-term protection in adults.

Included trials predominantly considered persons without prior $M t b$ sensitisation; however, the background intensity of $M t b$ transmission remains relevant to the relative importance of early and late reactivation (43). In settings of declining burden, TB episodes many years from vaccination are more likely to represent progression of infection acquired shortly following vaccination. Conversely, in high-burden settings, late-presenting episodes may result from later exposure. Under this conceptual framework, trials in both low- and high-burden settings will show high initial effectiveness, whereas later protection is dependent on transmission intensity. As late reactivation is commoner in adolescence and adulthood (14), these effects will be less apparent in studies that do not follow participants passing into adulthood. The recent BCG and H4:IC31 revaccination trial was conducted in adolescents in a high-burden setting. Both BCG and H4:IC31 boosting in those previously BCG vaccinated decreased persistent $M t b$ sensitisation, consistent with short-term protection from infection (16).

A non-significant effect in studies enrolling across a broad range of ages should not be interpreted as lesser protection in older participants, because such studies may include substantial 
medRxiv preprint doi: https://doi.org/10.1101/2020.11.26.20239533; this version posted November 30, 2020. The copyright holder for this

It is made available under a CC-BY-NC 4.0 International license .

cohorts of young children and follow-up invariably emphasises the early post-vaccination period.

Therefore, it is more likely that protection is present in young children, but offset by adverse effects in adults in the late post-vaccination period. An example is the Chengalpattu trial which reported considerable protection in children aged $<15$ during the first 12.5 years of follow-up (40), but with a marginally deleterious effect in the trial overall.

Our framework for understanding BCG efficacy is biologically plausible because the most favourable outcome following exposure is stable immune tolerance, and because the immunology of TB differs fundamentally between infants, children and adults (10). Infants, with a developing adaptive immune system and reduced capacity of antigen-presenting cells, develop a disease phenotype similar to that observed in HIV-1-infected individuals. This results in higher mortality and more frequent disseminated TB in infants, but is ameliorated by BCG priming trained immunity and enhancing early $M t b$ containment (44). Ages 5 to 14 years represent an epidemiological paradox of low TB risk despite high $M t b$ exposure in high-burden settings (45). During this pre-adolescent period, boosting natural immunity to TB through vaccination may be less important, although BCG also protects against respiratory viruses, possibly through "trained" innate immunity (46). Differing from classical T and B cell immune memory, trained immunity refers to epigenetic modulation of innate immune cells; in the case of BCG, monocyte, NK and $\gamma \delta$ T-cells demonstrate enhanced IFN $\gamma$, TNF, IL- 6 and IL- $1 \beta$ production though DNA chromatin relaxation at these gene promoters. From around age 15, TB risk dramatically increases and the phenotype of disease changes to classic pulmonary cavitary disease. If by 15 to 20 years post-vaccination acquired $\mathrm{T}$ cell protection wanes but trained innate immunity persists, then the host will have lost the beneficial BCG-related effects of T-cell-mediated immunity, but acquired a persistent hyper-reactive innate response. Such a response is seen in the 
transcriptional signatures predictive of TB risk, and may be responsible for the liquefactive necrosis that leads to clinical symptoms, organ damage and transmission in adults (47). Therefore, because TB disease is immunologically mediated, it is plausible that induced T cell sensitisation to a broad range of $M t b$ antigens could protect against the first encounter with the organism during an age of suboptimal immunity. However, it may have a reduced or adverse effect with repeated exposure in adulthood, when the immunological response is vastly different to that of infants, for whom BCG is clearly effective.

Past reviews have proposed that between-trial heterogeneity may be partially explained by latitudinal gradient in non-tuberculous mycobacteria (NTMs) exposure, particularly in studies employing one-stage TST testing (4). These arguments require that: 1) NTM sensitisation decreases with latitude, 2) TST positivity detectable only with two-stage testing frequently represents sensitisation to NTMs rather than $M t b, 3)$ NTM sensitisation confers immunity to $M t b$, and 4) because of NTM-conferred immunity to $M t b$, BCG vaccination boosts immunity to $M t b$ to a lesser extent in those with NTM sensitisation than those without. Although point 1 ) is well-established, latitudinal gradient also applies for $M t b$. To our knowledge, evidence is conflicting for point 2) (36) and derived from animal models for points 3) (48) and 4) (49). The greater rates of TB observed in NTM-naïve persons at an equivalent TST response (50) likely reflect a greater probability of $M t b$ infection. Re-analysis of the Chengalpattu study suggested somewhat lower protection in NTM-sensitised participants (51), although the statistical significance of this finding was unclear, while the one trial conducted across sites at multiple latitudes found similar effects by location (30). Although we do not discount the importance of NTM sensitisation, a greater effect of vaccination on clearly TST-negative participants and young children would also support our hypothesis. That is, if the lower efficacy of BCG distant 
medRxiv preprint doi: https://doi.org/10.1101/2020.11.26.20239533; this version posted November 30, 2020. The copyright holder for this

It is made available under a CC-BY-NC 4.0 International license .

from vaccination is attributable to accumulated exposure to $M t b$, then exposure to both $M t b$ and NTMs could have similar effects in mitigating vaccine efficacy. As such, the recent success of the M72/AS01 trial in Mtb-exposed, predominantly BCG-vaccinated adults in a high-burden setting, supports the need for revaccination with new antigens to mitigate any increased risk from past BCG vaccination (52).

We therefore believe that our hypothesis is supported by the evidence to a considerably greater extent than previously accepted explanations. However, as is common in empiric research, not every aspect of the analysis is perfectly consistent with the hypothesis. For example, our hypothesis does not explain the slight adverse effect suggested in the Georgia schools trial, although the very small number of cases is consistent with random chance and heterogeneity was not observed in this trial category. We also expected more TB cases in the vaccinated group late from enrolment in the Chengalpattu trial, which was seen to only a minor extent. As previously suggested, this may be explained by high rates of pre-existing Mtb exposure in both the control and vaccinated participants because of one-stage TST testing.

We propose that BCG vaccination protects against early post-vaccination exposure to Mtb, but is less effective or may increase rates of disease with later exposure, that the results of most or all past trials of BCG vaccination are consistent with this hypothesis and that this framework is more plausible than previously proposed explanations. We believe this explanation is also highly intuitive in retrospect, but may not have been recognised previously because Mtb sensitisation at recruitment has generally been excluded in trial participants based on TST. This phenomenon is infrequently observed because it is only seen in studies with long follow-up undertaken in highburden settings, which are also the most logistically challenging to perform. Given that no clinical trial has found a statistically significant increased risk of disease, the increased rates of 
medRxiv preprint doi: https://doi.org/10.1101/2020.11.26.20239533; this version posted November 30, 2020. The copyright holder for this preprint (which was not certified by peer review) is the author/funder, who has granted medRxiv a license to display the preprint in perpetuity.

It is made available under a CC-BY-NC 4.0 International license .

TB from late post-vaccination Mtb exposure may or may not represent an increased lifetime risk in high-burden settings. However, deferring episodes of disease could still have extremely important epidemiological effects, given that paediatric TB more often results in serious sequelae, whereas adult TB is more infectious and critical to perpetuating the epidemic. It is essential that future studies of TB risk and the effect of BCG vaccination present results disaggregated by age and time from exposure to fully elucidate these distinct reactivation profiles. 
medRxiv preprint doi: https://doi.org/10.1101/2020.11.26.20239533; this version posted November 30, 2020. The copyright holder for this preprint (which was not certified by peer review) is the author/funder, who has granted medRxiv a license to display the preprint in perpetuity.

It is made available under a CC-BY-NC 4.0 International license .

\section{Acknowledgements}

We express our great thanks to the staff of the National Institute for Research in Tuberculosis for providing the disaggregated results used to generate the last panel of Figure 3, including Dr

Srikanth Tripathy, Basilea Watson and others. We also gratefully acknowledge the contribution of the following individuals who assisted with data extraction for non-English language papers:

Eike Steinig, Maddalena Cerrone and Joanna Zając.

\section{Conflict of interest}

We declare no competing interests. 


\section{References}

1. World Health Organization. Global tuberculosis report 2019. doi:.1037//0033-

2909.I26.1.78.

2. World Health Organization. World immunization profile. 2020. Available at <http://www.who.int/immunization/monitoring_surveillance/data/gs_gloprofile.pdf?ua=1>.

3. Colditz GA, Berkey CS, Mosteller F, Brewer TF, Wilson ME, Burdick E, Fineberg H V. The efficacy of bacillus Calmette-Guérin vaccination of newborns and infants in the prevention of tuberculosis: meta-analyses of the published literature. Pediatrics 1995;96:29-35.

4. Mangtani P, Abubakar I, Ariti C, Beynon R, Pimpin L, Fine PE, Rodrigues LC, Smith PG, Lipman M, Whiting PF, Sterne JA. Protection by BCG vaccine against tuberculosis: a systematic review of randomized controlled trials. Clin Infect Dis 2014;58:470-480.

5. Abubakar I, Pimpin L, Ariti C, Beynon R, Mangtani P, Sterne J, Fine P, Smith P, Lipman M, Elliman D, Watson J, Drumright L, Whiting P, Vynnycky E, Rodrigues L. Systematic review and meta-analysis of the current evidence on the duration of protection by bacillus CalmetteGuérin vaccination against tuberculosis. Heal Technol Assess 2013;17:1-372, v-vi.

6. Sterne JA, Rodrigues LC, Guedes IN. Does the efficacy of BCG decline with time since vaccination? Int J Tuberc Lung Dis 1998;2:200-7.

7. Rodrigues LC, Mangtani P, Abubakar I. How does the level of BCG vaccine protection against tuberculosis fall over time? BMJ 2011;343:d5974.

8. Dye C. Making wider use of the world's most widely used vaccine: Bacille CalmetteGuerin revaccination reconsidered. J R Soc Interface 2013;10:20130365. 
medRxiv preprint doi: https://doi.org/10.1101/2020.11.26.20239533; this version posted November 30, 2020. The copyright holder for this preprint (which was not certified by peer review) is the author/funder, who has granted medRxiv a license to display the preprint in perpetuity.

It is made available under a CC-BY-NC 4.0 International license .

9. Frimodt-Möller J, Acharyulu GS, Pillai KK. Observation concerning the protective effect of BCG vaccination in the rural population of South India: report number 4. Bull Int Union Tuberc 1973;48:40-52.

10. Seddon JA, Chiang SS, Esmail H, Coussens AK. The wonder years: What can primary school children teach us about immunity to mycobacterium tuberculosis? Front Immunol 2018;9:2946.

11. Nguipdop-Djomo P, Heldal E, Rodrigues LC, Abubakar I, Mangtani P. Duration of BCG protection against tuberculosis and change in effectiveness with time since vaccination in Norway: a retrospective population-based cohort study. Lancet Infect Dis 2016;16:219-26.

12. Mangtani P, Nguipdop-Djomo P, Keogh RH, Sterne JA, Abubakar I, Smith PG, Fine PE, Vynnycky E, Watson JM, Elliman D, Lipman M, Rodrigues LC. The duration of protection of school-aged BCG vaccination in England: a population-based case-control study. Int J Epidemiol 2018;47:193-201.

13. Sloot R, Schim van der Loeff MF, Kouw PM, Borgdorff MW. Risk of Tuberculosis after Recent Exposure. A 10-Year Follow-up Study of Contacts in Amsterdam. Am J Respir Crit Care Med 2014;190:1044-1052.

14. Melsew YA, Cheng AC, McBryde ES, Denholm JT, Tay E, Ragonnet R, Trauer JM. Profiles of tuberculosis disease activation among contacts of patients with tuberculosis. Eur Respir J 2019;54:1900353.

15. Marais BJ, Gie RP, Schaaf HS, Hesseling AC, Obihara CC, Starke JJ, Enarson DA, Donald PR, Beyers N. The natural history of childhood intra-thoracic tuberculosis: a critical review of literature from the pre-chemotherapy era. Int J Tuberc Lung Dis 2004;8:392-402. 
medRxiv preprint doi: https://doi.org/10.1101/2020.11.26.20239533; this version posted November 30, 2020. The copyright holder for this preprint (which was not certified by peer review) is the author/funder, who has granted medRxiv a license to display the preprint in perpetuity.

It is made available under a CC-BY-NC 4.0 International license .

16. Nemes E, Geldenhuys H, Rozot V, Rutkowski KT, Ratangee F, Bilek N, Mabwe S,

Makhethe L, Erasmus M, Toefy A, Mulenga H, Hanekom WA, Self SG, Bekker L-G, Ryall R,

Gurunathan S, DiazGranados CA, Andersen P, Kromann I, Evans T, Ellis RD, Landry B, Hokey

DA, Hopkins R, Ginsberg AM, Scriba TJ, Hatherill M. Prevention of M. tuberculosis Infection

with H4:IC31 Vaccine or BCG Revaccination. N Engl J Med 2018;379:138-149.

17. Colditz GA, Brewer TF, Berkey CS, Wilson ME, Burdick E, Fineberg H V, Mosteller F. Efficacy of BCG vaccine in the prevention of tuberculosis. Meta-analysis of the published literature. J Am Med Assoc 1994;271:698-702.

18. Ferguson RG, Simes AB. BCG vaccination of Indian infants in Saskatchewan. Tubercle 1949;30:5-11.

19. Aronson JD. Protective vaccination against Tuberculosis with special reference to BCG vaccination. Am Rev Tuberc 1948;58:255-81.

20. Levine M, Vogel P, Rosenberg H. Immunization against Tuberculosis: A Study of the Essential Factors. Am Rev Tuberc 1938;38:632-43.

21. Rosenthal SR, Loewinsohn E, Graham ML, Liveright D, Thorne MG, Johnson V, Baison HC. BCG Vaccination against Tuberculosis in Chicago. Pediatrics 1961;28:622-41.

22. Rosenthal S. Immunologic aspects of BCG vaccination: A strictly controlled study in infants from tuberculous households. J Pediatr 1950;36:399-420.

23. Mehta KP, Merchant SM, Korde U. Environmental influence on immunity due to BCG vaccination. Indian Pediatr 1976;13:525-32. 
medRxiv preprint doi: https://doi.org/10.1101/2020.11.26.20239533; this version posted November 30, 2020. The copyright holder for this preprint (which was not certified by peer review) is the author/funder, who has granted medRxiv a license to display the preprint in perpetuity.

It is made available under a CC-BY-NC 4.0 International license .

24. Levine MI. Exposure of Tuberculin-sensitive Children to Exogenous Infection with Human Tubercle Bacilli. Arch Pediatr Adolesc Med 1941;61:1238.

25. Mehrotra AK, Dabral SB, Nandan D, Maheshwari BB, Shrotriya V, Prakash B, Gupta SC. Assessment of efficacy of BCG vaccination among slum children of Agra City. Indian J Public Health 1988;32:164-5.

26. Rosenthal S, Leslie E, Loewinsohn E. BCG vaccination in all age groups, Methods and results of a strictly controlled study. J Am Med Assoc 1948;136:73-9.

27. Vandiviere H, Dworski M, Melvin I, Watson K, Begley J. Efficacy of Bacillus CalmetteGuerin and isoniazid-resistant Bacillus Calmette-Guerin with and without isoniazid chemoprophylaxis from day of vaccination. Am Rev Respir Dis 1973;108:301-13.

28. Aronson NE, Santosham M, Comstock GW, Howard RS, Moulton LH, Rhoades ER, Harrison LH. Long-term Efficacy of BCG Vaccine in American Indians and Alaska Natives. $J$ Am Med Assoc 2004;291:2086.

29. Palmer CE, Shaw LW, Comstock GW. Community trials of BCG vaccination. Am Rev Tuberc 1958;77:877-907.

30. Palmer CE, Shaw LW. Present status of BCG studies. Am Rev Tuberc 1953;68:462-6.

31. Aronson JD, Aronson CF, Taylor HC. A twenty-year appraisal of BCG vaccination in the control of tuberculosis. AMA Arch Intern Med 1958;101:881-93.

32. Shaw LW. Field studies on immunization against tuberculosis. I. Tuberculin allergy following BCG vaccination of school children in Muscogee County, Georgia. Public Heal reports $1951 ; 66: 1415-6$. 
medRxiv preprint doi: https://doi.org/10.1101/2020.11.26.20239533; this version posted November 30, 2020. The copyright holder for this preprint (which was not certified by peer review) is the author/funder, who has granted medRxiv a license to display the preprint in perpetuity.

It is made available under a CC-BY-NC 4.0 International license .

33. Hart PD, Sutherland I. BCG and vole bacillus vaccines in the prevention of tuberculosis in adolescence and early adult life. Br Med J 1977;2:293-5.

34. Tuberculosis Vaccines and Clinical Trials Committee. BCG and vole bacillus vaccines in the prevention of tuberculosis in adolescents first (progress) report to the Medical Research Council by their tuberculosis vaccines clinical trials committee. $\operatorname{Br}$ Med $J$ 1956;1:413-27.

35. Rosenthal SR, Afremow ML, Nikurs L, Loewinsohn E, Leppmann M, Katele E, Liveright D, Thorne M. BCG vaccination and tuberculosis in students of nursing. Am J Nurs $1963 ; 63: 88-93$.

36. Rosenthal SR, Colbert MJ, Nikurs L. Tuberculin reaction trends and BCG vaccination. Arch Environ Health 1965;11:794-803.

37. Coetzee AM, Berjak J. B.C.G. in the prevention of tuberculosis in an adult population. Proc Mine Med Off Assoc 1968;48:41-53.

38. Bettag OL, Kaluzny AA, Morse D, Radner DB. BCG Study at a State School for Mentally Retarded. Dis Chest 1964;45:503-507.

39. Baily G V. Tuberculosis prevention Trial, Madras. Indian J Med Res 1980;72 Suppl:174.

40. Tripathy SP. The case for B.C.G. Ann Natl Acad Med Sci 1983;19:11-21.

41. Frimodt-Moller J, Thomas J, Parthasarathy R. Observations on the Protective Effect of BCG Vaccination in a South Indian Rural Population. Bull World Health Organ 1964;30:545574. 
medRxiv preprint doi: https://doi.org/10.1101/2020.11.26.20239533; this version posted November 30, 2020. The copyright holder for this preprint (which was not certified by peer review) is the author/funder, who has granted medRxiv a license to display the preprint in perpetuity.

It is made available under a CC-BY-NC 4.0 International license .

42. Frimodt-Moller J. A community-wide tuberculosis study in a South Indian rural population, 1950-1955. Bull World Health Organ 1960;22:61-170.

43. Ragonnet R, Trauer JM, McBryde ES, Houben RMGJ, Denholm JT, Handel A, Sumner T. Is IPT more effective in high-burden settings? Modelling the effect of tuberculosis incidence on IPT impact. Int J Tuberc Lung Dis 2017;21:60-6.

44. Zufferey C, Germano S, Dutta B, Ritz N, Curtis N. The Contribution of NonConventional T Cells and NK Cells in the Mycobacterial-Specific IFN $\gamma$ Response in Bacille Calmette-Guérin (BCG)-Immunized Infants. In: Rodrigues MM, editor. PLoS One 2013;8:819835.

45. Basu Roy R, Whittaker E, Seddon JA, Kampmann B. Tuberculosis susceptibility and protection in children. Lancet Infect Dis 2019;

46. Netea MG, Van Crevel R. BCG-induced protection: Effects on innate immune memory. Semin Immunol 2014;

47. Dannenberg AM. Immune mechanisms in the pathogenesis of pulmonary tuberculosis. Rev Infect Dis 1989;11 Suppl 2:S369-78.

48. Fine PEM. Variation in protection by BCG: implications of and for heterologous immunity. Lancet 1995;346:1339-45.

49. Brandt L, Cunha JF, Olsen AW, Chilima B, Hirsch P, Appelberg R, Andersen P. Failure of the Mycobacterium bovis BCG vaccine: Some species of environmental mycobacteria block multiplication of BCG and induction of protective immunity to tuberculosis. Infect Immun 2002;70:672-678. 
medRxiv preprint doi: https://doi.org/10.1101/2020.11.26.20239533; this version posted November 30, 2020. The copyright holder for this preprint (which was not certified by peer review) is the author/funder, who has granted medRxiv a license to display the preprint in perpetuity.

It is made available under a CC-BY-NC 4.0 International license .

50. Edwards LB, Acquaviva FA, Livesay VT. Identification of tuberculous infected. Dual tests and density of reaction. Am Rev Respir Dis 1973;108:1334-9.

51. Narayanan PR. Influence of sex, age \& nontuberculous infection at intake on the efficacy of BCG: re-analysis of 15-year data from a double-blind randomized control trial in South India. Indian J Med Res 2006;123:119-24.

52. Van Der Meeren O, Hatherill M, Nduba V, Wilkinson RJ, Muyoyeta M, Van Brakel E, Ayles HM, Henostroza G, Thienemann F, Scriba TJ, Diacon A, Blatner GL, Demoitie MA, Tameris M, Malahleha M, Innes JC, Hellstrom E, Martinson N, Singh T, Akite EJ, Khatoon Azam A, Bollaerts A, Ginsberg AM, Evans TG, Gillard P, Tait DR. Phase 2b controlled trial of M72/AS01E vaccine to prevent tuberculosis. N Engl J Med 2018;379:1621-1634.

53. Ferguson R, Simes A. BCG vaccination of Indian infants in Saskatchewan: A study carried out with financial assistance from the National Research Council of Canada. Tubercle 1949;30:5-11.

54. Lerner BH. New York City's tuberculosis control efforts: The historical limitations of the “war on consumption.” Am J Public Health 1993;83:758-766.

55. Neiman IS, Loewinsohn E. Inhibition of Primary Tuberculosis by BCG: A Study in Children, Based on 13,470 Chest Roentgenograms. Am Rev Tuberc 1947;56:27-35.

56. Rosenthal SR, Loewinsohn E, Graham ML, Liveright D, Thorne MG, Johnson V, Batson HC. BCG Vaccination against Tuberculosis in Chicago. Pediatrics 1961;28:622-41. 
medRxiv preprint doi: https://doi.org/10.1101/2020.11.26.20239533; this version posted November 30, 2020. The copyright holder for this preprint (which was not certified by peer review) is the author/funder, who has granted medRxiv a license to display the preprint in perpetuity.

It is made available under a CC-BY-NC 4.0 International license .

57. Mehrotra AK, Dabral SB, Nandan D, Maheshwari BB, Shrotriya V, Prakash B, Gupta

SC. Assessment of efficacy of BCG vaccination among slum children of Agra City. Indian J Public Health 32:164-5.

58. Vandiviere HM, Dworski M, Melvin IG, Watson KA, Begley J. Efficacy of Bacillus Calmette-Guerin and isoniazid-resistant Bacillus Calmette-Guerin with and without isoniazid chemoprophylaxis from day of vaccination. Am Rev Respir Dis 1973;108:301-13.

59. Palmer CE, Shaw LW, Comstock GW. Community trials of BCG vaccination. Am Rev Tuberc 1958;77:877-907.

60. Rieder HL. Tuberculosis among American Indians of the contiguous United States. Public Health Rep 1989;104:653-7.

61. Palmer CE, Shaw LW. Present status of BCG studies. Am Rev Tuberc 1953;68:462-6.

62. Medical Research Council. BCG and vole bacillus vaccines in the prevention of tuberculosis in adolescence and early adult life. Bull World Heal Organ, 1972/01/01. 1972;46:371-385.

63. Rosenthal SR, Leslie EI, Loewinsohn E. BCG vaccination in all age groups, Methods and results of a strictly controlled study. J Am Med Assoc 1948;136:73-79.

64. Coetzee AM, Berjak J. BCG in the prevention of tuberculosis in an adult population. Proc Mine Med Off Assoc 1968;48:41-53.

65. Frimodt-Möller J, Acharyulu GS, Pillai KK. Observation concerning the protective effect of BCG vaccination in the rural population of South India: report number 4. Bull Int Union Tuberc 1973;48:40-52. 
medRxiv preprint doi: https://doi.org/10.1101/2020.11.26.20239533; this version posted November 30, 2020. The copyright holder for this preprint (which was not certified by peer review) is the author/funder, who has granted medRxiv a license to display the preprint in perpetuity. It is made available under a CC-BY-NC 4.0 International license .

66. Bettag OL, Kaluzny AA, Morse D, Radner DB. BCG Study at a State School for Mentally Retarded. Dis Chest 1964;45:503-507.

67. Tuberculosis Prevention Trial. Trial of BCG vaccines in south India for tuberculosis prevention: First report. Bull World Health Organ 1979;57:819-27. 
medRxiv preprint doi: https://doi.org/10.1101/2020.11.26.20239533; this version posted November 30, 2020. The copyright holder for this preprint (which was not certified by peer review) is the author/funder, who has granted medRxiv a license to display the preprint in perpetuity.

It is made available under a CC-BY-NC 4.0 International license .

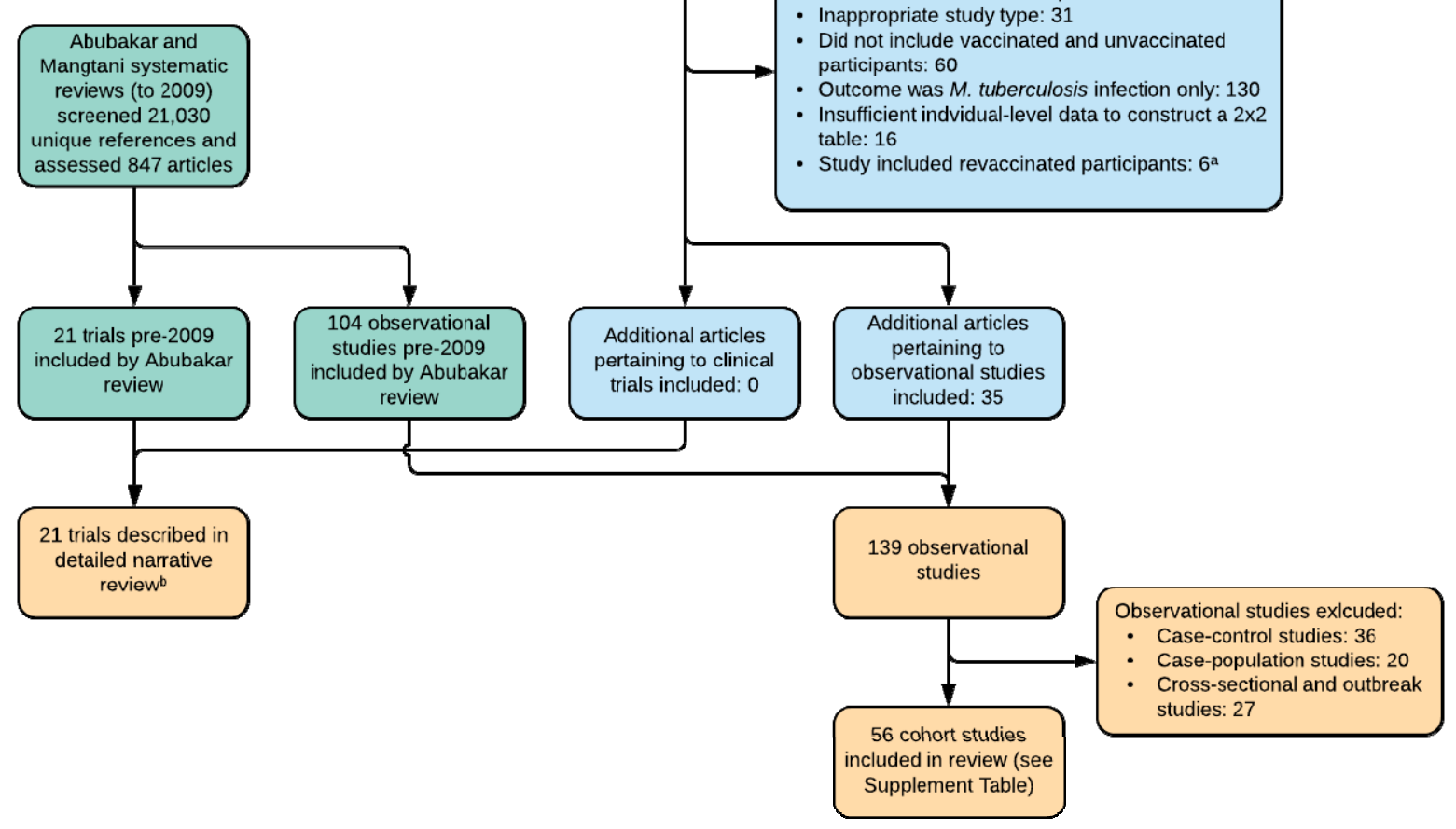

Figure 1. Modified PRISMA flow diagram. ${ }^{a}$ Includes two reports of one revaccination trial which observed zero cases of TB during follow-up. ${ }^{\text {b}}$ Studies in Chicago medical students, Chicago nursing students and New York infants not included in Mangtani review. 
medRxiv preprint doi: https://doi.org/10.1101/2020.11.26.20239533; this version posted November 30, 2020. The copyright holder for this preprint (which was not certified by peer review) is the author/funder, who has granted medRxiv a license to display the preprint in perpetuity.

It is made available under a CC-BY-NC 4.0 International license .
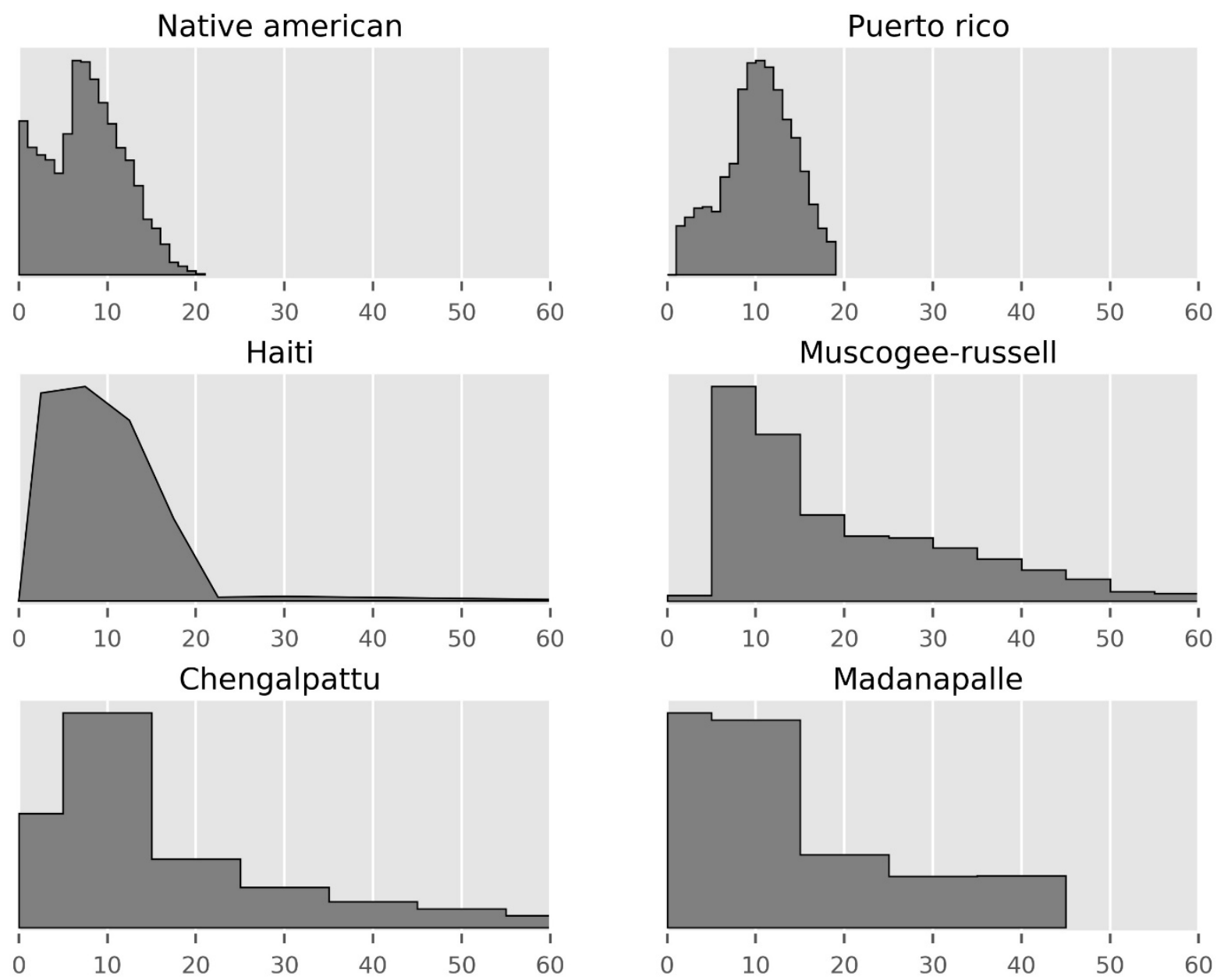

Figure 2. Age distribution (in years) of participants in studies for which these data were provided.

Studies with very narrow age inclusion criteria not presented (i.e. five neonatal trials and English cities trial of children aged 14 to $151 / 2$ years). All age distributions normalised to the same maximum vertical height. 
medRxiv preprint doi: https://doi.org/10.1101/2020.11.26.20239533; this version posted November 30, 2020. The copyright holder for this preprint (which was not certified by peer review) is the author/funder, who has granted medRxiv a license to display the preprint in perpetuity.

It is made available under a CC-BY-NC 4.0 International license .
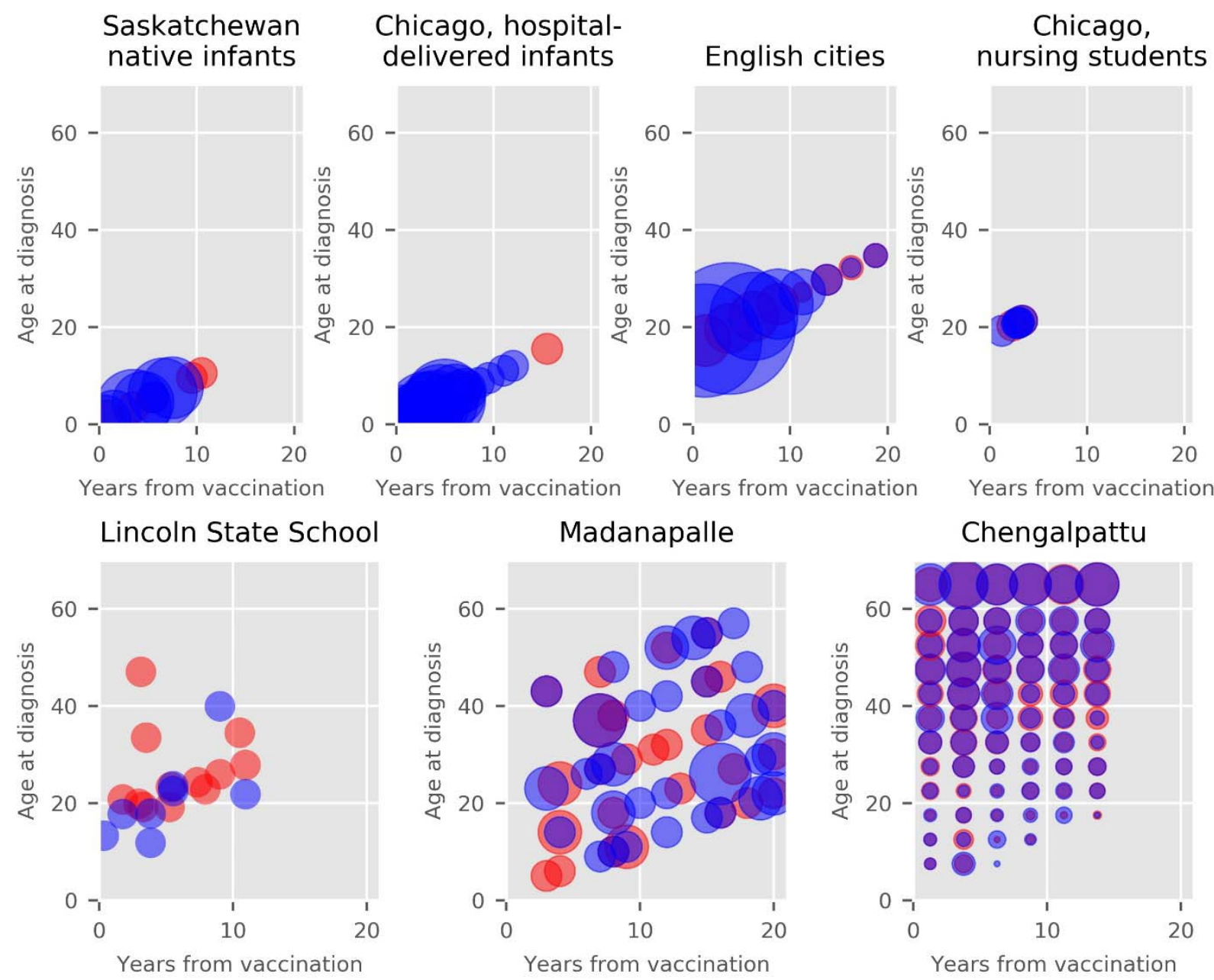

Figure 3. Distribution of cases of active TB occurring in the vaccinated (red) and unvaccinated (blue) populations in which timing of cases by age can be determined to within a five year interval.

Size of circles proportional to the number of cases where multiple cases occurred within a time/age interval. First six studies assigned to vaccinated and control in a 1:1 ratio, while Chengalpattu assigned in ratio of 2 BCG: 1 control, with the size of the vaccinated circles halved to compensate for this effect. Madanapalle panel presents results for bacteriologically-confirmed cases only. First panel data obtained from Table IV of Ferguson 1949, second panel data obtained from Figure 1 of Rosenthal 1961, third panel data obtained from Table 3 of Medical Research Council 1972, fourth panel data obtained from Table 3 of Rosenthal 1963, fifth panel data obtained from Tables 1 and 2 of Bettag 1964, sixth panel data obtained from Table 5 of Frimodt-Möller 1973, seventh panel presents previously unpublished data. 
medRxiv preprint doi: https://doi.org/10.1101/2020.11.26.20239533; this version posted November 30, 2020. The copyright holder for this preprint (which was not certified by peer review) is the author/funder, who has granted medRxiv a license to display the preprint in perpetuity.

It is made available under a CC-BY-NC 4.0 International license .

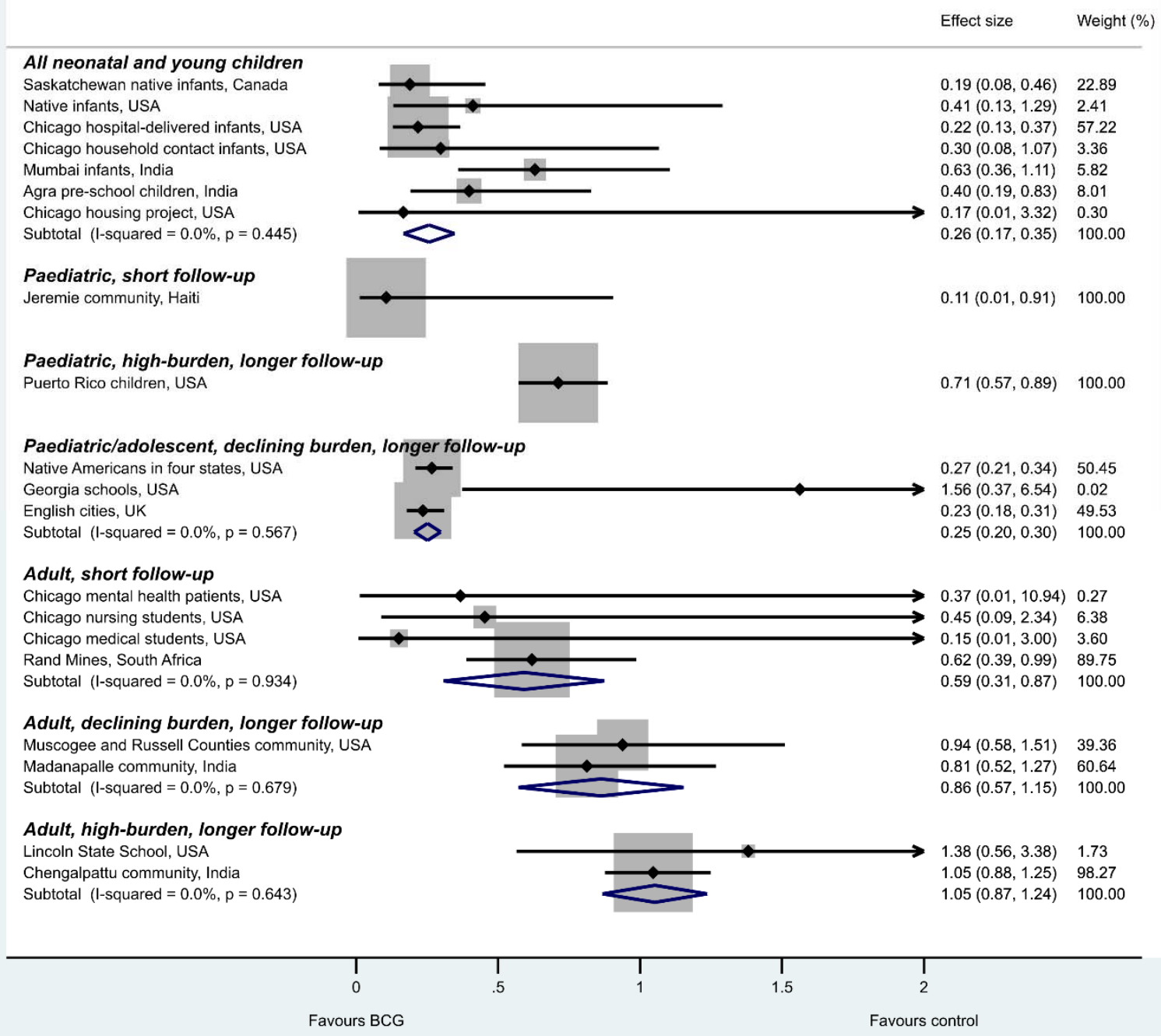

Figure 4. Forest plot of TB incidence rate ratios from trials of BCG vaccination by participant

demographics and background epidemiology. Pooled effects are from random effects meta-analysis.

Pooled estimates with confidence limits when using REML model with Stata 16.1 and Knapp-Hartung adjustments were: All neonatal and young children: 0.27 (0.15, 0.40); Paediatric/adolescent, declining burden, longer follow-up: 0.25 (0.17, 0.33); Adult, short follow-up: 0.59 (0.42, 0.77); Adult, declining burden, longer follow-up: $0.86(0.08,1.64)$, Adult, high-burden, longer follow-up: $1.05(0.50,1.61)$. New York infants trial not presented because only the outcome of TB-related deaths was reported from this trial. 
medRxiv preprint doi: https://doi.org/10.1101/2020.11.26.20239533; this version posted November 30, 2020. The copyright holder for this preprint (which was not certified by peer review) is the author/funder, who has granted medRxiv a license to display the preprint in perpetuity.

It is made available under a CC-BY-NC 4.0 International license.

\begin{tabular}{|l|l|l|l|}
\hline Setting & $\begin{array}{l}\text { Follow-up } \\
\text { period }^{\text {a }}\end{array}$ & Predominant reactivation profile & BCG \\
\hline Declining burden & Early & $\begin{array}{l}\text { Early progression from early } \\
\text { infection/exposure }\end{array}$ & High \\
\hline Declining burden & Late & $\begin{array}{l}\text { Late progression from early } \\
\text { infection/exposure }\end{array}$ & High \\
\hline Sustained high burden & Early & Early progression from early \\
infection/exposure & High \\
\hline Sustained high burden & Late & Early progression from late & Low or adverse \\
& & infection/exposure & \\
\hline
\end{tabular}

Table 1. Proposed conceptual framework for understanding the effect of BCG vaccination. ${ }^{a} E a r l y:$ approximately the first three to five years following vaccination; Late: greater than five years following vaccination. 


\begin{tabular}{|c|c|c|c|c|c|c|c|c|c|c|c|c|c|}
\hline Setting & $\begin{array}{l}\text { Age } \\
\text { profile }\end{array}$ & $\begin{array}{l}\text { Recruitme } \\
\text { nt start, } \\
\text { recruitmen } \\
\text { t end, } \\
\text { follow-up } \\
\text { end }\end{array}$ & $\begin{array}{l}\text { Long- } \\
\text { est } \\
\text { follow } \\
\text {-up } \\
\text { (years } \\
\text { ) }\end{array}$ & $\begin{array}{l}\text { Epidemiological } \\
\text { background }\end{array}$ & $\begin{array}{l}\text { Latitud } \\
\mathrm{e}\end{array}$ & $\begin{array}{l}\text { TST number, } \\
\text { dose }\end{array}$ & $\begin{array}{l}\text { TST } \\
\text { cut- } \\
\text { off } \\
(\mathrm{mm})\end{array}$ & $\begin{array}{l}\text { Follow- } \\
\text { up } \\
\text { screen } \\
\text {-ing }\end{array}$ & $\begin{array}{l}\text { Diagnostic } \\
\text { confirmation }\end{array}$ & $\begin{array}{l}\text { TB } \\
\text { endpoint } \\
\text { (authors' } \\
\text { terminolo } \\
\text { gy) }\end{array}$ & $\begin{array}{l}\text { Number } \\
\text { recruited } \\
\text { vaccinate } \\
\text { d, } \\
\text { controls }\end{array}$ & $\begin{array}{l}\text { TB cases in } \\
\text { vaccinated, } \\
\text { controls }\end{array}$ & $\begin{array}{l}\text { Incidence } \\
\text { rate ratio } \\
\text { point } \\
\text { estimate } \\
\text { (confidenc } \\
\text { e } \\
\text { intervals) }\end{array}$ \\
\hline $\begin{array}{l}\text { Saskatchewan } \\
\text { native infants, } \\
\text { Canada }\end{array}$ & $\begin{array}{l}\text { Neonate } \\
\mathrm{s}\end{array}$ & $\begin{array}{l}1933,1945 \\
1947\end{array}$ & 14 & $\begin{array}{l}\text { Rapidly declining } \\
\text { following period of } \\
\text { very high burden } \\
(53)\end{array}$ & $50.8 \mathrm{~N}$ & None & N/A & $\mathrm{X}$-ray & $\mathrm{X}$-ray and clinical & $\mathrm{TB}$ & 306,303 & 6,29 & $\begin{array}{r}0.19 \\
(0.08-0.46) \\
\\
\overline{\bar{\omega}}\end{array}$ \\
\hline $\begin{array}{l}\text { Native infants, } \\
\text { USA }\end{array}$ & $\begin{array}{l}\text { Neonate } \\
\mathrm{s}\end{array}$ & $\begin{array}{l}1938,1940, \\
1946\end{array}$ & 8 & $\begin{array}{l}\text { Rapidly declining } \\
\text { following period of } \\
\text { very high burden } \\
\text { (31) }\end{array}$ & $\begin{array}{l}48.8 \mathrm{~N} \\
\text { and } 43.2 \\
\mathrm{~N}\end{array}$ & None & N/A & $\begin{array}{l}\text { X-ray, } \\
\text { TST }\end{array}$ & $\begin{array}{l}\text { Routine diagnosis after } \\
\text { active follow-up ceased }\end{array}$ & Primary TB & 123,139 & 4,11 & 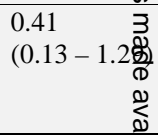 \\
\hline $\begin{array}{l}\text { New York infants, } \\
\text { USA }\end{array}$ & $\begin{array}{l}\text { Neonate } \\
\mathrm{s}\end{array}$ & $\begin{array}{l}1933,1944, \\
1944\end{array}$ & 11 & $\begin{array}{l}\text { Rapidly declining } \\
\text { following period of } \\
\text { very high burden } \\
(54)\end{array}$ & $40.7 \mathrm{~N}$ & $\begin{array}{l}\text { None (for } \\
\text { majority } \\
\text { vaccinated before } \\
\text { one month of } \\
\text { age) }\end{array}$ & N/A & $\begin{array}{l}\text { X-ray, } \\
\text { TST }\end{array}$ & $\begin{array}{l}\text { Microbiological or } \\
\text { autopsy }\end{array}$ & None & 566,528 & $\begin{array}{l}\text { Not reported } \\
\text { (TB-related } \\
\text { deaths: } 8,8 \text { ) }\end{array}$ & $\begin{array}{ll}\text { N/A } & \frac{\overline{0}}{\overline{0}} \\
\text { (TB } & \frac{0}{\Phi} \\
\text { mortality: } & \frac{5}{0} \\
0.93\left(0.35 \frac{0}{\Phi}\right. \\
2.49))\end{array}$ \\
\hline $\begin{array}{l}\text { Chicago hospital- } \\
\text { delivered infants, } \\
\text { USA }\end{array}$ & $\begin{array}{l}\text { Neonate } \\
\mathrm{s}\end{array}$ & $\begin{array}{l}1937,1956 \\
1956\end{array}$ & 19 & $\begin{array}{l}\text { Very high burden, } \\
\text { then rapidly } \\
\text { declining }(55,56)\end{array}$ & $41.9 \mathrm{~N}$ & None & N/A & $\begin{array}{l}\text { Clinical, } \\
\text { TST, } \mathrm{x}- \\
\text { ray }\end{array}$ & $\begin{array}{l}\text { Clinical, TST, } x \text {-ray, } \\
\text { autopsy (x-ray sufficient } \\
\text { for diagnosis) }\end{array}$ & TB & 5426,4128 & 18,63 & 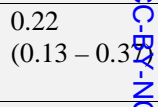 \\
\hline $\begin{array}{l}\text { Chicago } \\
\text { household contact } \\
\text { infants, USA }\end{array}$ & $\begin{array}{l}\text { Neonate } \\
\mathrm{s}\end{array}$ & $\begin{array}{l}1940,1955, \\
1955\end{array}$ & 15 & $\begin{array}{l}\text { Very high burden, } \\
\text { then rapidly } \\
\text { declining }(55,56)\end{array}$ & $41.9 \mathrm{~N}$ & $\begin{array}{l}\text { None (if mother } \\
\text { not the index) }\end{array}$ & N/A & $\begin{array}{l}\text { Clinical, } \\
\text { TST, } x- \\
\text { ray }\end{array}$ & $\begin{array}{l}\text { Clinical, TST, } x \text {-ray, } \\
\text { autopsy (x-ray sufficient } \\
\text { for diagnosis) }\end{array}$ & TB & 231,220 & 3,11 & $\begin{array}{lr}0.30 & \bar{\Omega} \\
(0.08-1.0 \text { 志 } & \overline{5} \\
\end{array}$ \\
\hline $\begin{array}{l}\text { Mumbai infants, } \\
\text { India }\end{array}$ & $\begin{array}{l}\text { Neonate } \\
\mathrm{s}\end{array}$ & $\begin{array}{l}1972,1972, \\
1975\end{array}$ & 2.5 & $\begin{array}{l}\text { Very high burden } \\
\text { (23) }\end{array}$ & $19.0 \mathrm{~N}$ & None & N/A & $\begin{array}{l}\text { Clinical, } \\
\text { TST }\end{array}$ & $\begin{array}{l}\text { TST sufficient for } \\
\text { diagnosis, although most } \\
\text { TB diagnoses had x-ray } \\
\text { changes }\end{array}$ & Primary TB & 396,300 & 22,27 & $\begin{array}{l}0.63 \\
(0.36-1.1 \text { 高) } \\
\text { 高 } \\
\text { 离 }\end{array}$ \\
\hline $\begin{array}{l}\text { Agra pre-school } \\
\text { children, India }\end{array}$ & $\begin{array}{l}0 \text { to } 5 \\
\text { years }\end{array}$ & $\begin{array}{l}1979,1979, \\
1984\end{array}$ & 5 & $\begin{array}{l}\text { Very high burden } \\
\text { (57) }\end{array}$ & $27.2 \mathrm{~N}$ & $\begin{array}{l}\text { One-stage, } \\
1 \text { TU PPD-RT23 }\end{array}$ & $<10$ & $\begin{array}{l}\text { X-ray, } \\
\text { sputum } \\
\text { examina } \\
\text { tion }\end{array}$ & Not stated & $\begin{array}{l}\text { Radiologica } \\
\text { lly active or } \\
\text { probably } \\
\text { active TB } \\
\end{array}$ & 1259,1259 & 10,25 & $\begin{array}{l}0.40 \quad \overline{\bar{\AA}} \\
\left(0.19-0.8 \frac{19}{\mathbb{C}_{0}}\right.\end{array}$ \\
\hline $\begin{array}{l}\text { Chicago housing } \\
\text { project, USA }\end{array}$ & $\begin{array}{l}0 \text { to } 12 \\
\text { years }\end{array}$ & $\begin{array}{l}1942,1955 \\
1955\end{array}$ & 13 & $\begin{array}{l}\text { High burden }(55, \\
56)\end{array}$ & $41.8 \mathrm{~N}$ & $\begin{array}{l}\text { Two-stage, } \\
\text { Vollmer then } 100 \\
\text { TU OT TST }\end{array}$ & $\begin{array}{l}\text { Not } \\
\text { stated }\end{array}$ & $\begin{array}{l}\text { X-ray, } \\
\text { TST }\end{array}$ & $\begin{array}{l}\text { Unclear, presumed x-ray } \\
\text { and clinical }\end{array}$ & $\begin{array}{l}\text { Active } \\
\text { pulmonary } \\
\text { TB }\end{array}$ & 947,944 & 0,3 & $\begin{array}{l}0.17 \\
(0.01-3.32)\end{array}$ \\
\hline $\begin{array}{l}\text { Jeremie } \\
\text { population-wide, } \\
\text { Haiti }\end{array}$ & $\begin{array}{l}\text { All } \\
\text { ages, } \\
\text { see } \\
\text { Figure } 2 \\
\end{array}$ & $\begin{array}{l}1965,1966, \\
1969\end{array}$ & 3 & $\begin{array}{l}\text { Very high burden } \\
\text { (58) }\end{array}$ & $18.6 \mathrm{~N}$ & $\begin{array}{l}\text { One-stage, } 5 \text { TU } \\
\text { PPD-S }\end{array}$ & $<6$ & $\begin{array}{l}\text { X-ray, } \\
\text { TST }\end{array}$ & Microbiological & TB & 635,338 & 1,5 & $\begin{array}{l}0.11 \\
(0.01-0.91)\end{array}$ \\
\hline $\begin{array}{l}\text { Puerto Rico } \\
\text { children, USA }\end{array}$ & $\begin{array}{l}1 \text { to } 18 \\
\text { years, } \\
\text { see } \\
\text { Figure } 2\end{array}$ & $\begin{array}{l}1949,1951, \\
1969\end{array}$ & 19.8 & $\begin{array}{l}\text { Declining but } \\
\text { substantial } \\
\text { following a period } \\
\text { of very high burden } \\
(59)\end{array}$ & $18.4 \mathrm{~N}$ & $\begin{array}{l}\text { Predominantly } \\
(\sim 76 \%) \text { two- } \\
\text { stage, } 1 \text { then } 10 \\
\text { TU PPD-RT19- } \\
20-21 \\
\end{array}$ & $<6$ & $\begin{array}{l}\text { No } \\
\text { active } \\
\text { follow- } \\
\text { up }\end{array}$ & $\begin{array}{l}\text { Existing surveillance } \\
\text { systems }\end{array}$ & TB & $\begin{array}{l}50634 \\
27338\end{array}$ & 186,141 & $\begin{array}{l}0.71 \\
(0.57-0.89)\end{array}$ \\
\hline
\end{tabular}




\begin{tabular}{|c|c|c|c|c|c|c|c|c|c|c|c|c|c|}
\hline $\begin{array}{l}\text { Native Americans } \\
\text { in four states, } \\
\text { USA }\end{array}$ & $\begin{array}{l}0 \text { to } 19 \\
\text { years, } \\
\text { see } \\
\text { Figure } 1\end{array}$ & $\begin{array}{l}1935,1938, \\
1998\end{array}$ & 63 & $\begin{array}{l}\text { Low and declining } \\
\text { following a period } \\
\text { of very high burden } \\
(60)\end{array}$ & $\begin{array}{l}32.2 \mathrm{~N} \\
\text { to } 58.8 \\
\mathrm{~N}\end{array}$ & $\begin{array}{l}\text { Two-stage, } \\
1 \text { then } 250 \mathrm{TU} \\
\text { PPD }\end{array}$ & $\begin{array}{l}\text { Not } \\
\text { stated }\end{array}$ & $\begin{array}{l}\text { X-ray, } \\
\text { TST }\end{array}$ & $\begin{array}{l}\text { X-ray during first } 12 \\
\text { years, then } \\
\text { microbiological, clinical } \\
\text { and other tests }\end{array}$ & $\begin{array}{l}\text { Radiologica } \\
1 \text { evidence } \\
\text { first } 11 \\
\text { years, then } \\
\text { by case } \\
\text { definitions }\end{array}$ & 1551,1457 & 84,280 & $\begin{array}{l}0.27 \\
(0.21-0.34)\end{array}$ \\
\hline $\begin{array}{l}\text { Georgia schools, } \\
\text { USA }\end{array}$ & $\begin{array}{l}6 \text { to } 17 \\
\text { years }\end{array}$ & $\begin{array}{l}1947,1947, \\
1967\end{array}$ & 20 & $\begin{array}{l}\text { Low and declining } \\
\text { following a period } \\
\text { of high burden (61) }\end{array}$ & $32.5 \mathrm{~N}$ & $\begin{array}{l}\text { Two-stage, } 5 \text { and } \\
100 \text { TU PPD- } \\
\text { RT19-20-21 }\end{array}$ & $<5$ & TST & $\begin{array}{l}\text { Clinical, } \\
\text { microbiological, x-ray, } \\
\text { TST }\end{array}$ & TB & 2498,2341 & 5,3 & $\begin{array}{l}1.56 \\
(0.37-6.54)\end{array}$ \\
\hline English cities, UK & $\begin{array}{l}14 \text { to } \\
15 \frac{1}{2} \\
\text { years }\end{array}$ & $\begin{array}{l}1950,1952, \\
1972\end{array}$ & 20 & $\begin{array}{l}\text { Low and declining } \\
\text { following a period } \\
\text { of high burden }(62)\end{array}$ & $\begin{array}{l}51.5 \mathrm{~N} \\
\text { to } 53.5 \\
\mathrm{~N}\end{array}$ & $\begin{array}{l}\text { Two-stage, } 3 \text { and } \\
100 \text { TU OT }\end{array}$ & $<5$ & $\begin{array}{l}\text { Clinical, } \\
\text { TST, x- } \\
\text { ray }\end{array}$ & $\begin{array}{l}\text { Clinical, } \\
\text { microbiological, } \\
\text { pathological }\end{array}$ & TB & $\begin{array}{l}13598 \\
12867\end{array}$ & 62,248 & 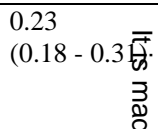 \\
\hline $\begin{array}{l}\text { Chicago mental } \\
\text { health patients, } \\
\text { USA }\end{array}$ & $\begin{array}{l}\text { Adults } \\
\text { up to } 66 \\
\text { years }\end{array}$ & $\begin{array}{l}1943,1947 \\
1947\end{array}$ & 4 & High burden (63) & $41.9 \mathrm{~N}$ & $\begin{array}{l}\text { Two-stage, } 100 \\
\text { TU OT }\end{array}$ & $\begin{array}{l}\text { Not } \\
\text { stated }\end{array}$ & $\begin{array}{l}\text { Not } \\
\text { stated }\end{array}$ & Not stated & $\begin{array}{l}\text { Pulmonary } \\
\text { TB }\end{array}$ & 20,15 & $\begin{array}{l}0,1 \\
\text { (unconfirmed } \\
\text { case) }\end{array}$ & 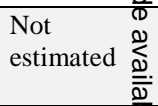 \\
\hline $\begin{array}{l}\text { Chicago nursing } \\
\text { students, USA }\end{array}$ & $\begin{array}{l}\text { Presum } \\
\text { ed } \\
\text { young } \\
\text { adult }\end{array}$ & $\begin{array}{l}1940,1953, \\
1956\end{array}$ & 3 & $\begin{array}{l}\text { High rates of } \\
\text { exposure, higher in } \\
\text { vaccinated (36) }\end{array}$ & $41.9 \mathrm{~N}$ & $\begin{array}{l}\text { Two-stage, } 2 \text { and } \\
10 \text { TU OT }\end{array}$ & $<6$ & TST & $\begin{array}{l}\text { Clinical, } x \text {-ray, other } \\
\text { tests (x-ray sufficient for } \\
\text { diagnosis) }\end{array}$ & TB & 231,263 & 2,5 & 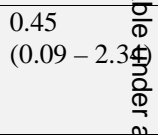 \\
\hline $\begin{array}{l}\text { Chicago medical } \\
\text { students, USA }\end{array}$ & $\begin{array}{l}20 \text { to } 37 \\
\text { years }\end{array}$ & $\begin{array}{l}1939,1952, \\
1964\end{array}$ & 4 & $\begin{array}{l}\text { High rates of } \\
\text { exposure (36) }\end{array}$ & $41.9 \mathrm{~N}$ & $\begin{array}{l}\text { Two-stage, } 2 \text { and } \\
\text { either } 10 \text { or } 100 \\
\text { TU OT }\end{array}$ & $<6$ & TST & $\begin{array}{l}\text { Clinical, } \mathrm{x} \text {-ray, } \\
\text { microbiological }\end{array}$ & TB & 324,298 & 0,3 & 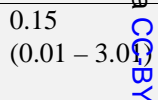 \\
\hline $\begin{array}{l}\text { Rand Mines, } \\
\text { South Africa }\end{array}$ & $\begin{array}{l}30.3 \pm \\
10.3 \\
\text { years }^{\mathrm{a}}\end{array}$ & $\begin{array}{l}1965,1968 \\
1968\end{array}$ & 3.6 & $\begin{array}{l}\text { Very high burden } \\
\text { (64) }\end{array}$ & $26.2 \mathrm{~S}$ & $\begin{array}{l}\text { None for most of } \\
\text { trial, then one- } \\
\text { stage for last } \\
\text { eight months }\end{array}$ & $\begin{array}{l}\text { Not } \\
\text { stated }\end{array}$ & X-ray & $\mathrm{X}$-ray & TB & 8317,7997 & 29,45 & 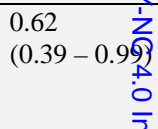 \\
\hline $\begin{array}{l}\text { Muscogee and } \\
\text { Russell Counties } \\
\text { population-wide, } \\
\text { USA }\end{array}$ & $\begin{array}{l}\text { See } \\
\text { Figure 2 }\end{array}$ & $\begin{array}{l}1950,1950 \\
1970\end{array}$ & 20 & $\begin{array}{l}\text { Low and declining } \\
\text { burden }(61)\end{array}$ & $32.5 \mathrm{~N}$ & $\begin{array}{l}\text { One-stage, } 5 \text { TU } \\
\text { PPD-RT-19-20- } \\
21\end{array}$ & $<5$ & None & $\begin{array}{l}\text { Existing surveillance } \\
\text { systems }\end{array}$ & TB & $\begin{array}{l}16913 \\
17854\end{array}$ & 32,36 & 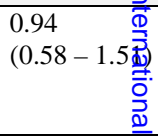 \\
\hline $\begin{array}{l}\text { Madanapalle } \\
\text { population-wide, } \\
\text { India }\end{array}$ & $\begin{array}{l}\text { See } \\
\text { Figure 2 }\end{array}$ & $\begin{array}{l}1950,1955 \\
1971\end{array}$ & 21 & $\begin{array}{l}\text { Very high burden, } \\
\text { rapidly declining } \\
\text { due to active case } \\
\text { finding }(65)\end{array}$ & $13.6 \mathrm{~N}$ & $\begin{array}{l}\text { Predominantly } \\
\text { one-stage } \\
(\sim 95 \%), 5 \text { TU } \\
\text { PPD-RT-19-20- } \\
21^{\text {b }}\end{array}$ & $<5$ & X-ray & $\begin{array}{l}\text { Clinical, } x \text {-ray, } \\
\text { microbiological, other } \\
\text { tests }\end{array}$ & $\begin{array}{l}\text { Bacteriolog } \\
\text { ically- } \\
\text { confirmed } \\
\text { TB }\end{array}$ & 5069,5808 & 33,47 & 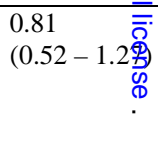 \\
\hline $\begin{array}{l}\text { Lincoln State } \\
\text { School, USA }\end{array}$ & $\begin{array}{l}\text { Not } \\
\text { stated }^{\text {a }}\end{array}$ & $\begin{array}{l}1947,1947, \\
1960\end{array}$ & 12 & $\begin{array}{l}\text { Declining but } \\
\text { substantial } \\
\text { following a period } \\
\text { of very high burden } \\
(66)\end{array}$ & $40.2 \mathrm{~N}$ & $\begin{array}{l}\text { Two-stage, } 10 \\
\text { and } 100 \text { TU OT }\end{array}$ & $\begin{array}{l}\text { Not } \\
\text { stated }\end{array}$ & $\begin{array}{l}\text { TST, } \mathrm{x}- \\
\text { ray }\end{array}$ & $\begin{array}{l}\text { Clinical, } \\
\text { microbiological, other } \\
\text { tests }\end{array}$ & TB & 531,494 & 12,8 & $\begin{array}{l}1.38 \\
(0.56-3.38)\end{array}$ \\
\hline $\begin{array}{l}\text { Chengalpattu } \\
\text { population-wide, } \\
\text { India }\end{array}$ & $\begin{array}{l}\text { See } \\
\text { Figure 2 }\end{array}$ & $\begin{array}{l}1968,1971, \\
1987\end{array}$ & 15 & $\begin{array}{l}\text { Very high burden } \\
\text { (67) }\end{array}$ & $12.7 \mathrm{~N}$ & $\begin{array}{l}\text { One-stage, } 3 \text { TU } \\
\text { PPD-S }\end{array}$ & $<8$ & $\begin{array}{l}\text { X-ray, } \\
\text { sputum } \\
\text { examina } \\
\text { tion }\end{array}$ & $\begin{array}{l}\text { Culture-positive on } \geq 1 \\
\text { sputum }\end{array}$ & $\begin{array}{l}\text { Culture- } \\
\text { confirmed } \\
\text { TB }\end{array}$ & $\begin{array}{l}78693 \\
39025\end{array}$ & 380,180 & $\begin{array}{l}1.05 \\
(0.88-1.25)\end{array}$ \\
\hline
\end{tabular}


Table 2. Studies of BCG vaccination not restricted to neonates. ${ }^{2} \mathrm{~TB}$ cases were aged 15 to 44, such that "school" does not imply children. UK, United Kingdom; USA, United States of America. Chicago mental health patients trial (of participants aged up to 66 years) not included because only one unconfirmed case of TB was observed. ${ }^{b}$ Our assessment differs importantly from that of Mangtani et al. 2014. Italicised years indicate inferred/assumed dates/follow-up periods. 


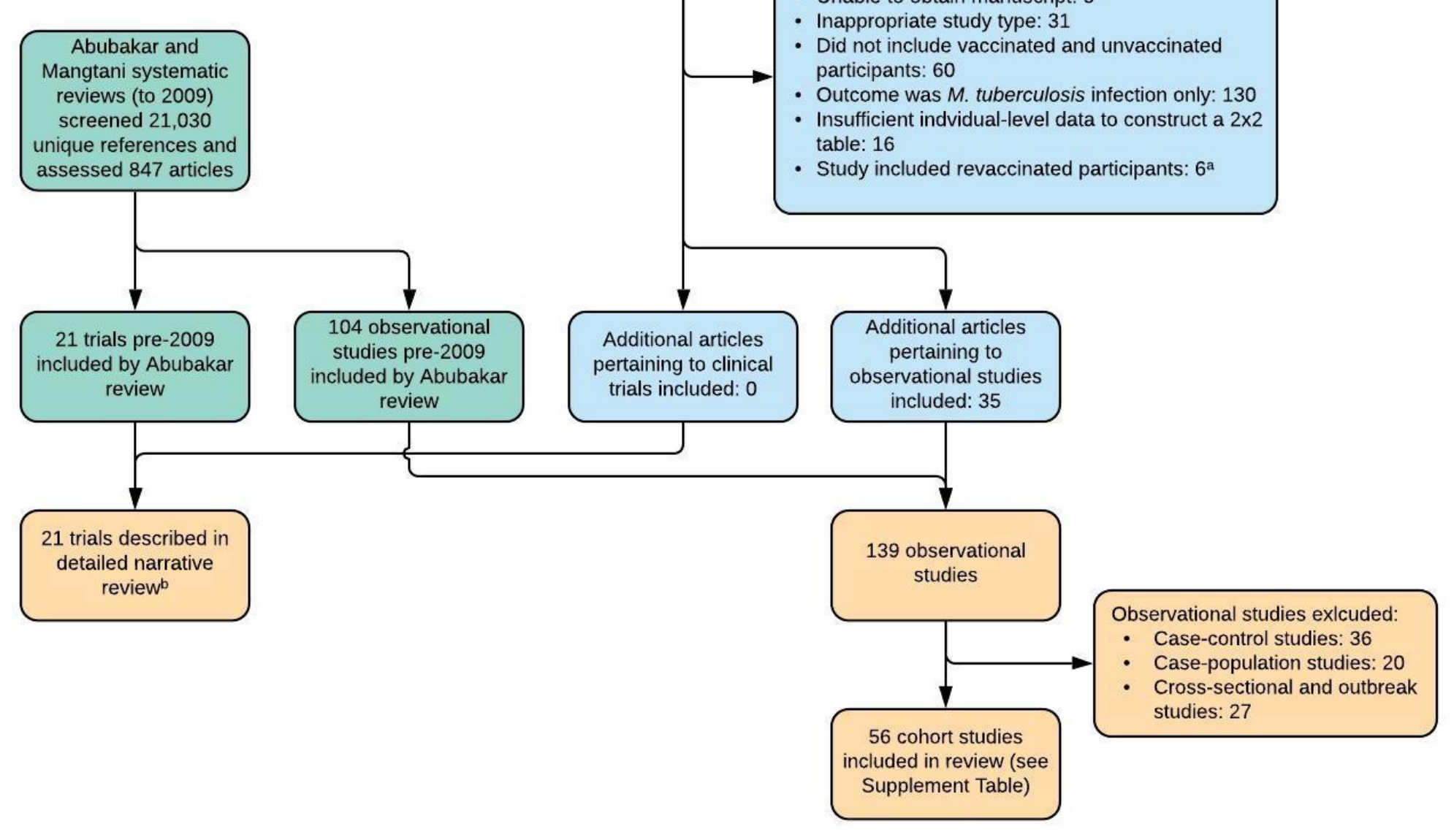


Native american
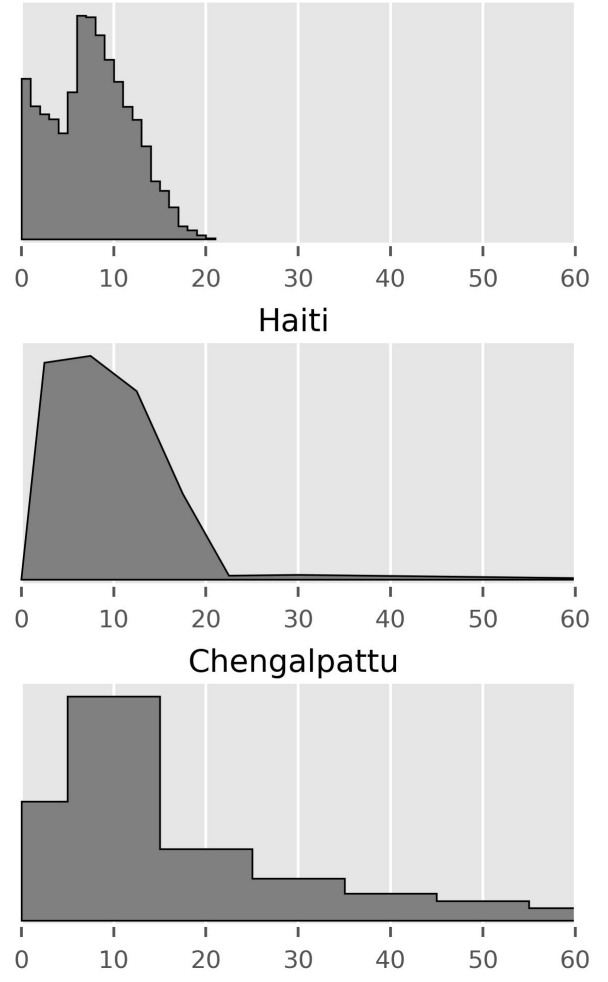

Puerto rico
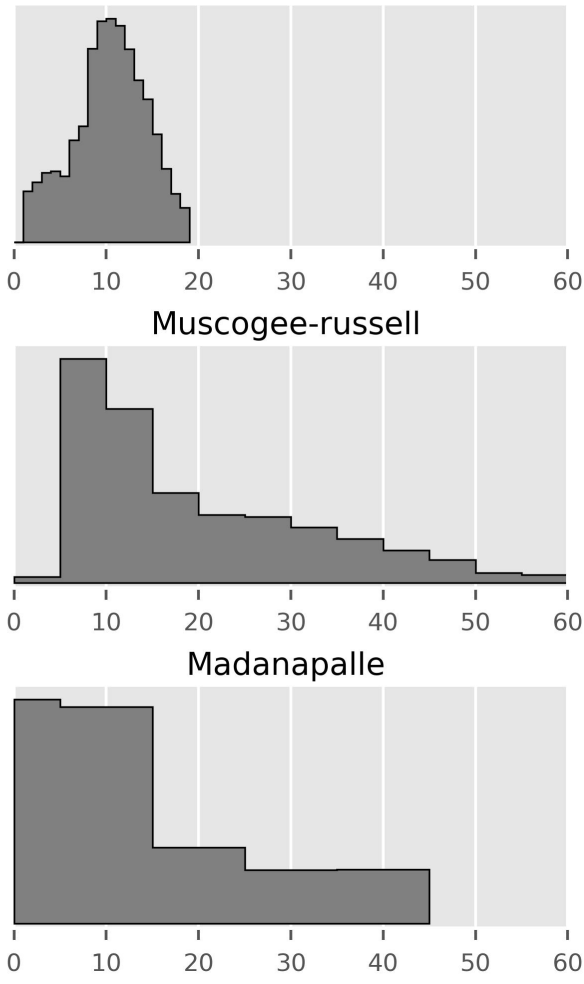
Saskatchewan native infants

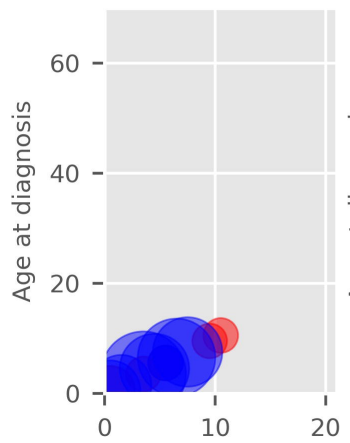

Years from vaccination
Chicago, hospitaldelivered infants

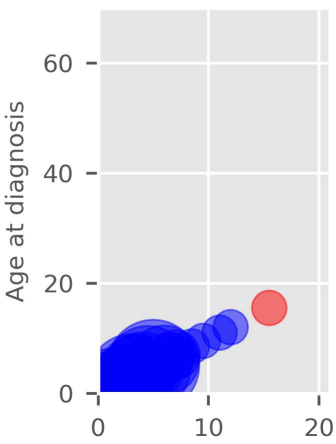

Years from vaccination

\section{English cities}

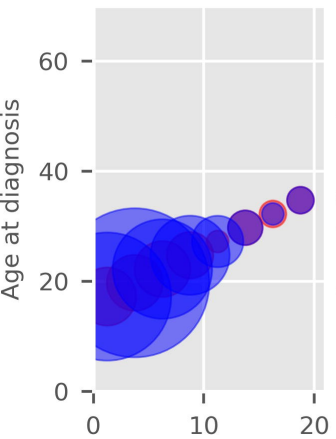

Chicago, nursing students
Lincoln State School

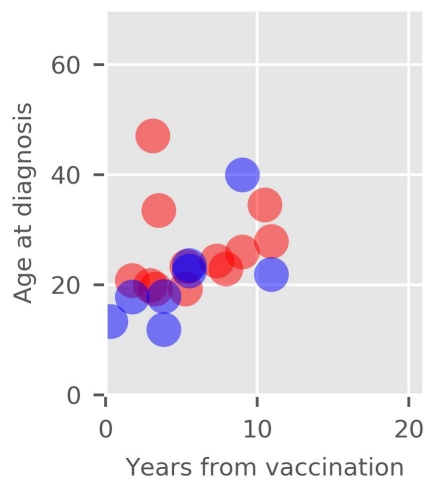

Madanapalle

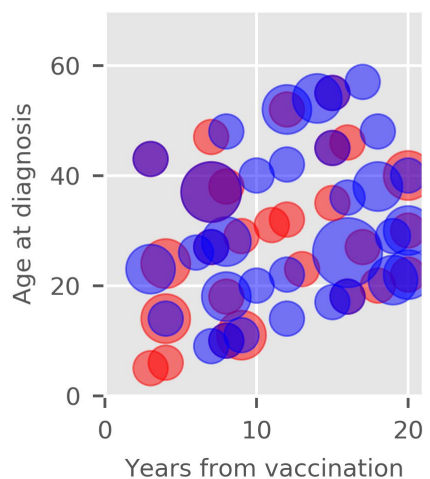

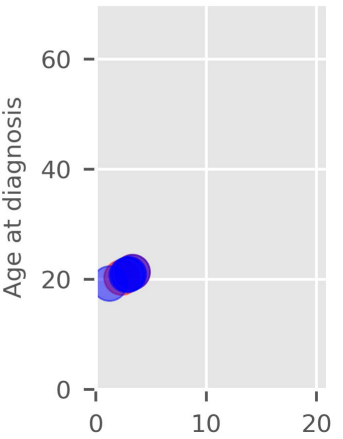

Years from vaccination

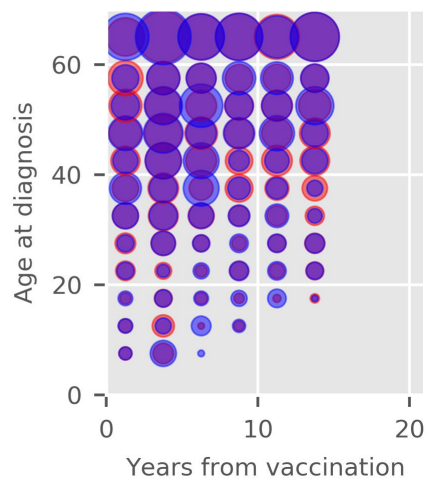




\section{All neonatal and young children}

Saskatchewan native infants, Canada

Native infants, USA Chicago household contact infants, USA Mumbai infants, India

Agra pre-school children, India

Chicago housing project, USA

Subtotal (I-squared $=0.0 \%, p=0.445$ )

\section{Paediatric, short follow-up}

Jeremie community, Haiti
Chicago hospital-delivered infants, USA

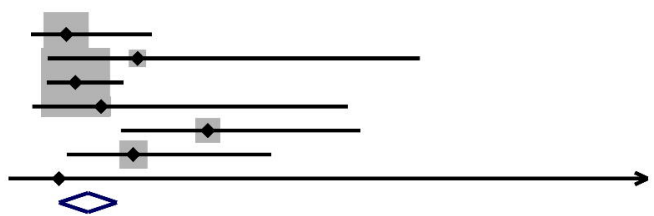

$0.19(0.08,0.46) \quad 22.89$

$0.41(0.13,1.29) \quad 2.41$

$0.22(0.13,0.37) \quad 57.22$

$0.30(0.08,1.07) \quad 3.36$

$0.63(0.36,1.11) \quad 5.82$

$0.40(0.19,0.83) \quad 8.01$

$0.17(0.01,3.32) \quad 0.30$

$0.26(0.17,0.35) \quad 100.00$

$0.11(0.01,0.91) \quad 100.00$

$0.71(0.57,0.89) \quad 100.00$

Paediatric, high-burden, longer follow-up

Puerto Rico children, USA

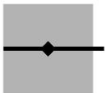

Paediatric/adolescent, declining burden, longer follow-up

Native Americans in four states, USA

Georgia schools, USA

English cities, UK

Subtotal (I-squared $=0.0 \%, p=0.567)$

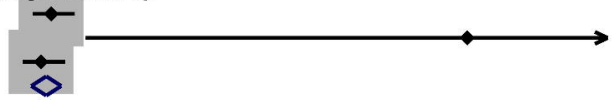

$0.27(0.21,0.34)$

$1.56(0.37,6.54)$

$0.23(0.18,0.31)$

$0.25(0.20,0.30)$

\section{Adult, short follow-up}

Chicago mental health patients, USA

Chicago nursing students, USA

Chicago medical students, USA

Rand Mines, South Africa

Subtotal $(\mid$-squared $=0.0 \%, p=0.934)$

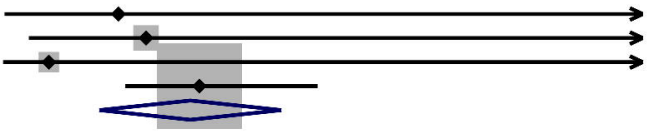

$0.37(0.01,10.94) 0.27$

$0.45(0.09,2.34) \quad 6.38$

$0.15(0.01,3.00) \quad 3.60$

$0.62(0.39,0.99) \quad 89.75$

$0.59(0.31,0.87) \quad 100.00$

Adult, declining burden, longer follow-up

Muscogee and Russell Counties community, USA

Madanapalle community, India

Subtotal $($ I-squared $=0.0 \%, p=0.679)$

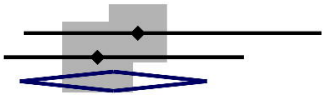

$0.94(0.58,1.51) \quad 39.36$

$0.81(0.52,1.27) \quad 60.64$

$0.86(0.57,1.15) \quad 100.00$

\section{Adult, high-burden, longer follow-up}

Lincoln State School, USA

Chengalpattu community, India

Subtotal (I-squared $=0.0 \%, p=0.643$ )

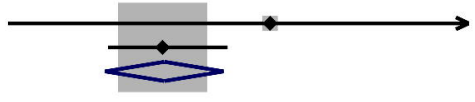

$1.38(0.56,3.38) \quad 1.73$

$1.05(0.88,1.25) \quad 98.27$

$1.05(0.87,1.24) \quad 100.00$ 